\title{
Traditional knowledge on the medicinal use of plants from genus Gentiana in the Pirot County (Serbia)
}

\author{
Marija Marković ${ }^{1, *}$, Dejan Pljevljakušić ${ }^{2}$, Nebojša Menković ${ }^{2}$, Jelena Matejić ${ }^{3}$, Olivera \\ Papović ${ }^{4}$, AND Vesna Stankov Jovanović ${ }^{3}$ \\ ${ }^{1}$ University of Niš, Faculty of Sciences and Mathematics, Department of Biology and Ecology, Višegradska 33, 18000 Niš, Serbia \\ ${ }^{2}$ Institute for Medicinal Plant Research "Dr. Josif Pančić", Tadeuša Koščuška 1, 11000 Belgrade, Serbia \\ ${ }^{3}$ University of Niš, Faculty of Medicine, Department of Pharmacy, Bulevar Dr. Zorana Einđića 81, 18000 Niš, Serbia \\ ${ }^{4}$ University of Priština temporarily settled in Kosovska Mitrovica, Faculty of Science and Mathematics, Lole Ribara 29, 38220 Kosovska Mitrovica, Serbia \\ *Corresponding author: marijam@pmf.ni.ac.rs
}

Published: December 25, 2021

Received: November 18, 2021

Accepted: December 1, 2021

Published on-line: December 10, 2021

\begin{abstract}
The paper provides an insight into the traditional use of medicinal plant species from the genus Gentiana in the Pirot County in Southeastern Serbia. The ethnopharmacological study was conducted in the form of interviews among the population in four municipalities: Pirot, Babušnica, Bela Palanka, and Dimitrovgrad. Among the population of Pirot County, it was noticed the use of two species from the genus Gentiana: G. cruciata and G. lutea. It was recorded that cross gentian (G. cruciata) has great popularity and versatile aspects on traditional usage, that was mentioned by 53 respondents, and that includes the treatment of cancer diseases, improving the immune system, diabetes, blood purification, for appetite, gastric and duodenal ulcer, for high blood pressure, inflammation, lung diseases, cold, cough, disease prevention, diseases of internal organs, high cholesterol, and leaking breast. The usage of the root of yellow gentian (G. lutea) was mentioned by 30 respondents, and that includes improving the immune system, appetite, for the stomach, blood purification, circulation, as an aphrodisiac, against cancer diseases, diabetes, and gastric and duodenal ulcer. It is important to note that yellow gentian, recorded in the study area, is the first species on the list of illegally collected species in Serbia.
\end{abstract}

Key words: Gentiana; Pirot County; traditional medicine

http://dx.doi.org/10.5937/leksir2141046M

\section{INTRODUCTION}

The efficacy of herbal medicinal products has been confirmed by many years of experience in traditional medicine. The use of medicinal plants became a growing tendency due to accessibility, wide range of therapeutic applications, safety, and low cost (Janaćković et al., 2019). According to the same authors, there is not much ethnobotanical evidence for East Serbia. Therefore, we conducted an ethnopharmacological study in Pirot County (Southeastern Serbia), situated on the border between Serbia and Bulgaria, which is a typical traditional and underdeveloped region of Serbia. This study was organized to increase the knowledge of medicinal flora on the Balkan Peninsula, as one of the most important centers of plant diversity in Europe (Zlatković et al., 2014).

The pharmacognosy map data of the Pirot's environment is known according to Mihajlov and Milojević (1985). Furthermore, Milojević and Mihajlov (1985) have noticed 208 species of medicinal plants and 788 native folk names, whereby most of them are characterized by the characteristics of the language of this region. A list of 326 medicinal herbs was compiled in the Pirot County by Marković et al. (2010), of which 60 were aromatic plants (Marković et al., 2009). Medicinal plants of the Gentiana genus which are part of Serbian medicinal flora and which were also noticed in the Pirot County, according to Marković et al. (2020), are Gentiana asclepiadea L., Gentiana cruciata L., Gentiana lutea L., and Gentiana punctata L.

A great abundance of medicinal plant resources in Pirot County creates opportunities for its rational use but also implies the need for its protection from overexploitation, and pressure on wild populations (Marković et al., 2010). G. lutea has been observed by the same authors at a few sites in very poor and fragile populations of the Stara Planina Mts. However, the high demand for raw material of yellow gentian root (Gentianae radix) and uncontrolled exploitation led to the devastation of natural populations and the inclusion of $G$. lutea in the ranks of strictly protected plant species worldwide (Marković et al., 2010; 2020). Collection, use, and market sales of plant species G. asclepiadea, G. cruciata and G. lutea are regulated by special legislation and can be considered as protected species, according to Serbian National legislative (OGRS, 2016). 
Gentiana asclepiadea, the willow gentian, occurs in open pasture or forest slopes on Stara Planina Mts. and Vlaška Mt. in the Pirot County (Marković et al., 2020). There are several traditional indications G. asclepiadea can be used for, which are described in the literature. Pančić mentioned that the underground parts of this plant, yellow as wax, are known among the people of Serbia as a remedy against jaundice (Sarić, 1989). Additionally, Tasić et al. (2001) reported that is used especially after jaundice. The underground parts of the G. asclepiadea are used for the same indications as the underground parts of the G. lutea (Sarić, 1989; Tasić et al., 2001). According to Randjelović et al. (1998), G. asclepiadea is used as a prophylactic agent, against digestive disorders, to improve appetite, against anemia, and for general strengthening of the immune system. Moreover, Tasić (2012) mentioned the use of roots of G. asclepiadea for loss of appetite, as a stomachic, against gall and liver disease.

Gentiana cruciata, commonly called cross gentian, is a herbaceous perennial native to grasslands, and dry meadows in Pirot County. The above-ground part of the species G. cruciata is used to stimulate appetite as described by Tucakov (Sarić, 1989). The same author noted that it is not toxic, although it is very bitter. Tasić et al. (2001) mentioned that G. cruciata is used as holagog and amarum. According to the mentioned authors, G. cruciata is considered a perspective species, which can be a quality substitution for the root of G. lutea. Tasić (2012) mentioned the use of aerial parts for loss of appetite, as a stomachic, as well as a component in homemade preparations showing beneficial effects in gall and liver diseases.

Gentiana lutea, the yellow gentian, grows in grassy alpine and sub-alpine pastures only on Stara Planina Mts. (Midžor, Beleđe, Kopren) in the Pirot County (Marković et al., 2020). In accordance with the European Medicines Agency monograph (EMA, 2018), the underground part of G. lutea, is used as traditional herbal medicine for temporary loss of appetite and mild dyspeptic/gastrointestinal disorders. Gostuški and Tucakov (according to Sarić (1989)) mention the usage of the root of G. lutea to stimulate appetite and in case of difficult digestion, help the secretion of glands in the mouth and stomach against anemia, and after serious illnesses. The same authors mentioned that it has been used to improve digestion, against circulatory disorders, and as a mild sedative. Tasić (2012) mentioned the use of root for loss of appetite, as a stomachic as well as a component in homemade preparations showing beneficial effects in gall and liver diseases. The largest amount of gentian root is consumed in the industry of alcoholic drinks for the production of bitter brandies and liqueurs (Sarić, 1989). Gentiana punctata was also recorded in the flora of Stara Planina Mts. (Tasić, 2012). It is an official replacement or substitute for the root of $G$. lutea.

The study aimed to collect, analyze and evaluate traditional knowledge of two gentian species (G. cruciata and G. lutea) which were mentioned by respondents in the Pirot County, open possibilities for their rational exploitation in accordance with principles of protected species in Serbia, regulated by national legislation, and promote their cultivation near to their natural habitats, and therefore accelerate economic progress of this rural and underdeveloped region of Serbia.

\section{MATERIALS AND METHODS}

\subsection{Study area}

Investigated area of Pirot County is situated in the Balkan Peninsula, on the border between Serbia and Bulgaria, at altitudes 239 to $2169 \mathrm{~m}$. It includes four municipalities Pirot, Babušnica, Bela Palanka and Dimitrovgrad. The mountain ranges in the Pirot municipality are: the Stara Planina Mts, part of Vidlič, Belava, Sedlar, Vlaška Mts, in Bela Palanka municipality: Šljivovička Mt and Svrljiške Mts, in Babušnica municipality Suva Planina Mts and Ruj Mt, and in Dimitrovgrad municipality the Greben Mt and part of Vidlič Mt. The mentioned mountains are rich in medicinal plant species (Marković et al., 2019; 2010; 2009; Zlatković and Bogosavljević, 2014). Stara Planina Mts dominates the relief of Pirot County. It represents the richest mountain in terms of medicinal plants (Marković et al., 2010).

\subsection{Data collection}

Research about the knowledge and application of medicinal plants in the Pirot County was conducted by interviewing the population of four municipalities of this county: Pirot, Babušnica, Bela Palanka, and Dimitrovgrad. The survey was conducted using a semi-structured questionnaire. The questions were about general information about mentioned species, the indications, and the way of application of medicinal herbs. The population of 144 villages of Pirot County was included, with 631 persons, of which 337 were male and 294 were female (Marković, 2019; Stankov-Jovanović et al., 2018).

Plant vouchers that were collected in the study area were authenticated according to Josifović (1970-1986), Jordanov (19631979) and Tutin et al. (1964-1980). The nomenclature of the taxa was compiled from databases: The EURO+MED PlantBase (Euro+Med, 2006-) and GPC - Global Plant Checklist (The Catalogue of Life Partnership., 2017). The species collected were labeled and deposited in the herbarium collection at the Department of Biology and Ecology, Faculty of Sciences and Mathematics, the University of Niš "Herbarium Moesiacum Niš" (HMN). The voucher numbers for species mentioned during research are 14132 for G. cruciata, and 14133 for G. lutea. Original questionnaire data are also deposited in the HMN herbarium

\subsection{Data analysis}

The results of interviews are presented in alphabetical order of villages in four municipalities (Table 1 and 2). The data were entered in the columns: municipality, village or the name of the place of residence, gender, nationality, age, form in which the medicinal plant is applied, medicinal use, and therapeutic group. A comparison with the results of previous studies was performed by analyzing the ethnopharmacological applications of gentian species in neighboring regions of the Balkan Peninsula.

\section{RESULTS AND DISCUSSION}

\subsection{Quantitative analysis}

During the investigation, we recorded 3754 use reports of medicinal plants concerned human medicine, of which 83 reports refer to applications of plants from genus Gentiana (2.21 $\%)$. Among the local population of Pirot County, two species of the Gentianaceae family were mentioned by respondents $G$. cruciata and G. lutea. Of the total number of the interviewed population about two species of genus Gentiana, 83 persons knew about them, of which 68 of them were Serbian nationality and 15 were Bulgarian nationality. Among respondents, a total of 55 were male, and 28 were female. In Pirot municipality, species of Gentianaceae family were known to 58 respondents, in municipality Babušnica 5, in municipality Bela Palanka 5, and municipality Dimitrovrgad 15 interviewed people.

\subsection{Application of Gentiana cruciata in Pirot County}

Cross gentian (G. cruciata) is also known as "otodovka", "otodevka", „prostrel“ or "plava lincura" to the local popula- 
Table 1. Overview of the survey results in the Pirot County population about the application of cross gentian (Gentiana cruciata)

\begin{tabular}{|c|c|c|c|c|c|c|c|}
\hline Municipality & Village & Gender & Nationality & Age & Form & Use & Group $^{a}$ \\
\hline Pirot & Barje Čiflik & M & Serbian & 74 & extract & Inflammation & En \\
\hline Pirot & Bela & M & Serbian & 57 & extract & Gastric and duodenal ulcer & $\mathrm{Dg}$ \\
\hline Pirot & Blato & $\mathrm{M}$ & Serbian & 34 & extract & Gastric and duodenal ulcer & $\mathrm{Dg}$ \\
\hline Pirot & Velika Lukanja & M & Serbian & 63 & extract & For appetite & $\mathrm{Dg}$ \\
\hline Pirot & Velika Lukanja & M & Serbian & 62 & water macerate & Cancer diseases & $\mathrm{Ca}$ \\
\hline Pirot & Velika Lukanja & $\mathrm{F}$ & Serbian & 58 & water macerate & Cancer diseases & $\mathrm{Ca}$ \\
\hline Pirot & Visočka Ržana & M & Serbian & 66 & extract & High blood presure & $\mathrm{Cd}$ \\
\hline Pirot & Vlasi & $\mathrm{F}$ & Serbian & 42 & extract & Cold & Rs \\
\hline Pirot & Gnjilan & $\mathrm{F}$ & Serbian & 65 & extract & Diabetes & En \\
\hline Pirot & Gostuša & $\mathrm{F}$ & Serbian & 65 & extract & Diabetes & En \\
\hline Pirot & Gostuša & M & Serbian & 52 & water macerate & Cancer diseases & $\mathrm{Ca}$ \\
\hline Pirot & Gostuša & M & Serbian & 66 & water macerate & Cancer diseases & $\mathrm{Ca}$ \\
\hline Pirot & Gostuša & M & Serbian & 59 & extract & Blood purification & Dp \\
\hline Pirot & Dojkinci & $\mathrm{F}$ & Serbian & 56 & extract & Improving the immune system & $\operatorname{Pr}$ \\
\hline Pirot & Dojkinci & $\mathrm{F}$ & Serbian & 46 & extract & Uniknown use & $\mathrm{Vr}$ \\
\hline Pirot & Zaskovci & $\mathrm{M}$ & Serbian & 79 & water macerate & Cancer diseases & $\mathrm{Ca}$ \\
\hline Pirot & Izvor & $\mathrm{M}$ & Serbian & 67 & water macerate & Cancer diseases & $\mathrm{Ca}$ \\
\hline Pirot & Izvor & $\mathrm{F}$ & Serbian & 57 & extract & High cholesterol & $\mathrm{Cd}$ \\
\hline Pirot & Izvor & $\mathrm{F}$ & Serbian & 64 & extract & Improving the immune system & $\operatorname{Pr}$ \\
\hline Pirot & Jelovica & $\mathrm{M}$ & Serbian & 53 & extract & Cough & Rs \\
\hline Pirot & Jelovica & $\mathrm{F}$ & Serbian & 56 & extract & Blood purification & $\mathrm{Dp}$ \\
\hline Pirot & Krupac & $\mathrm{M}$ & Serbian & 59 & extract & Inflammation & If \\
\hline Pirot & Oreovica & $\mathrm{F}$ & Serbian & 58 & water macerate & Cancer diseases & $\mathrm{Ca}$ \\
\hline Pirot & Oreovica & $\mathrm{F}$ & Serbian & 37 & water macerate & Cancer diseases & $\mathrm{Ca}$ \\
\hline Pirot & Pakleštica & $\mathrm{M}$ & Serbian & 73 & extract & Improving the immune system & $\operatorname{Pr}$ \\
\hline Pirot & Pakleštica & M & Serbian & 33 & extract & Diabetes & En \\
\hline Pirot & Pokrevenik & M & Serbian & 64 & extract & Diabetes & En \\
\hline Pirot & Pokrevenik & $\mathrm{F}$ & Serbian & 47 & extract & Diabetes & En \\
\hline Pirot & Ponor & M & Serbian & 77 & extract & Diabetes & En \\
\hline Pirot & Slavinja & M & Bulgarian & 60 & extract & Uniknown use & $\mathrm{Vr}$ \\
\hline Pirot & Sopot & $\mathrm{F}$ & Serbian & 73 & water macerate & Cancer diseases & $\mathrm{Ca}$ \\
\hline Pirot & Topli Do & M & Serbian & 62 & extract & Diabetes & En \\
\hline Pirot & Topli Do & M & Serbian & 62 & extract & For appetite & $\mathrm{Dg}$ \\
\hline Pirot & Topli Do & $\mathrm{M}$ & Serbian & 62 & extract & Improving the immune system & $\operatorname{Pr}$ \\
\hline Pirot & Crnoklište & $\mathrm{F}$ & Serbian & 52 & extract & Disease prevention, instead of coffe & $\operatorname{Pr}$ \\
\hline Babušnica & Dol & $\mathrm{F}$ & Serbian & 72 & water macerate & Cancer diseases & $\mathrm{Ca}$ \\
\hline Babušnica & Radinjince & $\mathrm{F}$ & Serbian & 62 & extract & Leaking breast & $\mathrm{Rp}$ \\
\hline Babušnica & Crvena Jabuka & $\mathrm{M}$ & Serbian & 67 & extract & Uniknown use & $\mathrm{Vr}$ \\
\hline Bela Palanka & Klisura & $\mathrm{F}$ & Serbian & 59 & water macerate & Cancer diseases & $\mathrm{Ca}$ \\
\hline Bela Palanka & Novo Selo & M & Serbian & 75 & extract & Improving the immune system & $\operatorname{Pr}$ \\
\hline Dimitrovgrad & Vlkovija & $\mathrm{F}$ & Bulgarian & 61 & water macerate & Cancer diseases & $\mathrm{Ca}$ \\
\hline Dimitrovgrad & Gornji Krivodol & $\mathrm{F}$ & Bulgarian & 60 & water macerate & Cancer diseases & $\mathrm{Ca}$ \\
\hline Dimitrovgrad & Dragovita & M & Bulgarian & 57 & extract & Improving the immune system & $\operatorname{Pr}$ \\
\hline Dimitrovgrad & Dragovita & $\mathrm{M}$ & Bulgarian & 72 & extract & High blood presure & $\mathrm{Cd}$ \\
\hline Dimitrovgrad & Izatovci & M & Serbian & 52 & extract & Improving the immune system & $\operatorname{Pr}$ \\
\hline Dimitrovgrad & Petrlaš & M & Bulgarian & 37 & extract & Improving the immune system & $\operatorname{Pr}$ \\
\hline Dimitrovgrad & Radejna & $\mathrm{M}$ & Bulgarian & 61 & extract & For appetite & $\mathrm{Dg}$ \\
\hline Dimitrovgrad & Radejna & M & Bulgarian & 61 & extract & Blood purification & Dp \\
\hline Dimitrovgrad & Radejna & $\mathrm{F}$ & Bulgarian & 51 & extract & Blood purification & $\mathrm{Dp}$ \\
\hline Dimitrovgrad & Smilovci & $\mathrm{F}$ & Bulgarian & 50 & extract & Blood purification & $\mathrm{Dp}$ \\
\hline Dimitrovgrad & Smilovci & $\mathrm{F}$ & Bulgarian & 50 & extract & Lung diseases & Rs \\
\hline Dimitrovgrad & Trnski Odorovci & M & Bulgarian & 57 & extract & Lung diseases & Rs \\
\hline Dimitrovgrad & Trnski Odorovci & $\mathrm{M}$ & Bulgarian & 27 & extract & Diseases of internal organs & $\mathrm{Vr}$ \\
\hline
\end{tabular}

a Group abbreviations, Ca - Cancerous, Cd - Cardiovascular, Dg - Digestive, Dp - Depurative, En - Endocrinology, If - Infectious, Pr - Preventive, Rp Reproductive, Rs - Respiratory, Vr - Various. 
Table 2. Overview of the survey results in the Pirot County population about the application of yellow gentian (Gentiana lutea)

\begin{tabular}{|c|c|c|c|c|c|c|c|}
\hline Municipality & Village & Gender & Nationality & Age & Form & Use & Group $^{a}$ \\
\hline Pirot & Veliki Jovanovac & M & Serbian & 42 & extract & Improving the immune system & $\operatorname{Pr}$ \\
\hline Pirot & Veliko Selo & $\mathrm{F}$ & Serbian & 43 & extract & Improving the immune system & $\operatorname{Pr}$ \\
\hline Pirot & Gnjilan & M & Serbian & 41 & extract & Improving the immune system & $\operatorname{Pr}$ \\
\hline Pirot & Gostuša & M & Serbian & 53 & water macerate & Improving the immune system & $\operatorname{Pr}$ \\
\hline Pirot & Dojkinci & M & Serbian & 67 & extract & For stomach & $\mathrm{Dg}$ \\
\hline Pirot & Dojkinci & $\mathrm{F}$ & Serbian & 46 & water macerate & Improving the immune system & $\mathrm{Pr}$ \\
\hline Pirot & Izvor & $\mathrm{F}$ & Serbian & 63 & extract & Improving the immune system & $\operatorname{Pr}$ \\
\hline Pirot & Jelovica & M & Serbian & 85 & extract & For circulation & $\mathrm{Cd}$ \\
\hline Pirot & Jelovica & M & Serbian & 85 & extract & For stomach & $\mathrm{Dg}$ \\
\hline Pirot & Jelovica & M & Serbian & 85 & extract & Aphrodisiac & $\mathrm{Rp}$ \\
\hline Pirot & Jelovica & $\mathrm{F}$ & Serbian & 56 & water macerate & For stomach & $\mathrm{Dg}$ \\
\hline Pirot & Milojkovac & M & Serbian & 66 & extract & Improving the immune system & $\mathrm{Pr}$ \\
\hline Pirot & Oreovica & M & Serbian & 42 & extract & Improving the immune system & $\operatorname{Pr}$ \\
\hline Pirot & Oreovica & $\mathrm{F}$ & Serbian & 58 & extract & Improving the immune system & $\operatorname{Pr}$ \\
\hline Pirot & Pakleštica & M & Serbian & 72 & extract & Improving the immune system & $\operatorname{Pr}$ \\
\hline Pirot & Pokrevenik & M & Serbian & 64 & extract & Diabetes & En \\
\hline Pirot & Pokrevenik & M & Serbian & 64 & extract & Gastric and duodenal ulcer & Dg \\
\hline Pirot & Pokrevenik & M & Serbian & 64 & extract & Blood purification & $\mathrm{Dp}$ \\
\hline Pirot & Sukovo & M & Serbian & 63 & water macerate & For appetite & $\mathrm{Dg}$ \\
\hline Pirot & Topli Do & M & Serbian & 76 & water macerate & Blood purification & Dp \\
\hline Pirot & Topli Do & M & Serbian & 76 & water macerate & Cancer diseases & $\mathrm{Ca}$ \\
\hline Pirot & Topli Do & M & Serbian & 62 & water macerate & For appetite & Dg \\
\hline Pirot & Topli Do & M & Serbian & 62 & water macerate & Blood purification & Dp \\
\hline Babušnica & Dol & M & Serbian & 62 & extract & For appetite & $\mathrm{Dg}$ \\
\hline Babušnica & Zavidince & $\mathrm{F}$ & Serbian & 44 & water macerate & Improving the immune system & $\mathrm{Pr}$ \\
\hline Bela Palanka & Divljana & M & Serbian & 61 & extract & For appetite & Dg \\
\hline Bela Palanka & Divljana & M & Serbian & 61 & extract & For circulation & $\mathrm{Cd}$ \\
\hline Bela Palanka & Leskovik & M & Serbian & 45 & extract & Improving the immune system & $\operatorname{Pr}$ \\
\hline Dimitrovgrad & Gornji Krivodol & M & Bulgarian & 75 & water macerate & For stomach & Dg \\
\hline Dimitrovgrad & Kusa Vrana & M & Bulgarian & 39 & extract & For appetite & $\mathrm{Dg}$ \\
\hline
\end{tabular}

a Group abbreviations, Ca - Cancerous, Cd - Cardiovascular, Dg - Digestive, Dp - Depurative, En - Endocrinology, Pr - Preventive, Rp - Reproductive. 
tion of Pirot County. The local folk names "otodevka" and "prostrel" refer to when a person is "shot" by a disease he should drink macerate prepared with cold water or extract in homemade alcoholic drink from this plant so that the disease goes away "otide" according to the local dialect. A total of 53 interviewed persons mentioned the cross gentian and its medicinal usage (Table 1). The majority of interviewed persons mentioned the use of the above-ground plant part of the cross gentian (G. cruciata) in the form of macerate prepared with cold water in the treatment of cancer diseases (13 respondents), improving the immune system (8 respondents), and treatment of diabetes ( 7 persons). In the blood purification, the cross gentian's above-ground plant part (Gentianae cruciatae herba) was mentioned by 5 respondents. The use for appetite was mentioned by 3 respondents, and the same number of people unknown use. In the treatment of gastric and duodenal ulcers, the usage of cross gentian above-ground plant parts was known to 2 respondents, and the same number of persons was familiar with its treatment for high blood pressure, inflammation, and lung diseases. One interviewed person mentioned usage of cross gentian above-ground plant part for cold, cough, disease prevention, diseases of internal organs, high cholesterol, and leaking breast.

\subsection{Application of Gentiana lutea in Pirot County}

Yellow gentian (G. lutea) is also known as "lincura" to the local population of Pirot County. A total of 30 interviewed persons mentioned the yellow gentian and its medicinal usage (Table 2) in the form of macerate in homemade traditional fruit brandy, called "Rakija" (20 respondents) or in the form of macerate prepared with cold water (10 respondents). Rakija is collective term for fruit spirits (or fruit brandy) popular in the Balkans, where the alcohol content is normally $40 \%(\mathrm{v} / \mathrm{v})$ and sometimes up to $50 \%(\mathrm{v} / \mathrm{v})$. The majority of interviewed persons mentioned the use of the yellow gentian (G. lutea) for improving the immune system (12 respondents). The usage for appetite was mentioned by five respondents. The usage for stomach was mentioned by four interviewed person and the usage for blood purification by three respondents. The usage of yellow gentian for circulation was known to 2 respondents. One interviewed person mentioned the usage of yellow gentian root as an aphrodisiac, against cancer diseases, diabetes, and gastric and duodenal ulcer.

\subsection{Therapeutic groups and comparison of applications with other studies in neighboring regions on Balkan Penin- sula}

\subsubsection{Therapeutic groups}

We summarized the applications of gentian species used in Pirot County in ten therapeutic groups (Table 3). The most common uses of the aboveground part of G. cruciata are against cancer diseases, for preventive treatments, in digestive troubles and endocrinology therapeutic group, and the most common form of application is as macerate in traditional fruit brandy. Macerate can be prepared and used, with the aboveground part of G. cruciata or the underground part of G. lutea for internal use for most of the mentioned diseases, especially to increase the appetite and help in digestive problems, and decreasing cholesterol in the blood.

\subsubsection{Comparison of applications of Gentiana cruciata with other} studies in neighboring regions on the Balkan Peninsula

Ethnopharmacological studies were performed also in neighboring regions on the Balkan Peninsula. Menković et al. (2011) studied the traditional usage of wild medicinal plants in the Prokletije Mountains (Montenegro). They mentioned the use of G. cruciata against loss of appetite, as a stomachic and component in preparations showing beneficial effects in gall and liver diseases. Zlatković and Bogosavljević (2014) studied the taxonomic and pharmacological valorization of medicinal plants of the Svrljiški Timok gorge in eastern Serbia. They emphasize the following effects of G. cruciata: stomachic, cholagogue, tonic, for appetite. They note that G. cruciata is one of the very popular plants in the folk medicine of this area, but not included in any of cited sources in lists of monographs on medicinal plants of World Health Organization (WHO, 2007). Jarić et al. (2015) mentioned that G. cruciata is the plant with the most phytotherapeutic uses on Suva Planina Mts. against cholesterol, diabetes, stomach ailments (stomach ulcers), improving appetite and the immune system, which is in line with our results. On the other hand, indications such as women's illness, to improve digestion, liver and gall bladder complaints, diseases related to the treatment of esophagus and chest diseases, blood detoxification, and anti-anemic were different in comparison to our study.

\subsubsection{Comparison of applications of Gentiana lutea with other stud-} ies in neighboring regions on the Balkan Peninsula

Similar to our results for the application of G. lutea were obtained in Serbia in general by Jarić et al. (2014), who did an ethnobotanical study about Serbian medieval medicine. They mentioned the following effects of yellow gentian: antidote in case of poisoning (snake or insect poison), antihelmintic, antihypertensive, blood detoxification, poor circulation, cold, carminative, diabetes, febrile conditions, gall bladder diseases, gastrointestinal tract disorders (diarrhea, regulating digestion, not specified gastrointestinal tract disorders, gastric ulcers, increasing appetite), liver disease, rheumatism, respiratory tract diseases (bronchitis, influenza), a stimulant.

Dajić Stevanović et al. (2014) also did an ethnobotanical study of the application of medicinal plants in Serbia in general. They state that the population of Serbia uses G. lutea for loss of appetite, as a stomachic, as well as a component in homemade preparations showing beneficial effects in gall and liver disease.

Pieroni et al. (2005) were mentioned a completely different use of G. lutea in Lëpushë, Northern Albanian Alps, as prevention against heart disease, macerated in cold water wild plum distillate for 1-2 days.

Menković et al. (2011) mentioned the same applications of $G$. lutea as the uses of G. cruciata against loss of appetite and as a stomachic, which was the same as our findings showed, and as a component in preparation showing beneficial effect in gall and liver diseases, which was different in comparison to our results.

Pieroni et al. (2011) have provided similar data in the study of the different applications of G. lutea growing in Western Serbia, Pešter plateau. They emphasize that G. lutea is used internally for the following indications: stomachache, stomach ulcer, diarrhea, treatment of cold and cough, and against rheumatism with the external form of application. The uses against digestive troubles were similar to our study, while the other uses were different.

Šavikin et al. (2013) mentioned the usage of G. lutea in Western Serbia, Zlatibor district, for treatments of digestive problems, which was similar to our study, and loss of appetite, which was different in comparison to our investigation.

Pieroni et al. $(2014 ; 2013)$ were also mentioned the use of G. lutea in Western Macedoinia and Eastern Albania. They were noted that the yellow gentian was dried and sold, and also largely gathered and traded in the past, but the use is unknown in those two regions. Among Albanians and Aromanians living in the Rraicë and Mokra areas of Eastern Albania, G. lutea is known as cardiotonic, which is similar to the results of Pieroni et al. (2005), but it is different with 
Table 3. Therapeutic groups with the frequency of reported indications of application for the traditional use of two gentian species in Pirot County

\begin{tabular}{|c|c|c|c|}
\hline \multirow[t]{2}{*}{ Therapeutic group } & \multirow[t]{2}{*}{ Indication } & \multicolumn{2}{|c|}{ Number of reports } \\
\hline & & G. cruciata & G. lutea \\
\hline Cancer diseases & Cancer & 13 & 1 \\
\hline \multirow[t]{2}{*}{ Preventive } & Improving the immune system & 8 & 12 \\
\hline & Disease prevention & 1 & - \\
\hline Endocrinology & Diabetes & 7 & 1 \\
\hline \multirow[t]{3}{*}{ Digestive } & For appetite & 3 & 5 \\
\hline & For stomach & - & 4 \\
\hline & Gastric and duodenal ulcer & 2 & 1 \\
\hline Depurative & Blood purification & 5 & 3 \\
\hline \multirow[t]{3}{*}{ Cardiovascular } & High blood pressure & 2 & - \\
\hline & For circulation & - & 2 \\
\hline & High cholesterol & 1 & - \\
\hline \multirow[t]{2}{*}{ Reproductive } & Leaking breast & 1 & - \\
\hline & Aphrodisiac & - & 1 \\
\hline Infectious & Inflammation & 2 & - \\
\hline \multirow[t]{3}{*}{ Respiratory } & Lung diseases & 2 & - \\
\hline & Cold & 1 & - \\
\hline & Cough & 1 & - \\
\hline \multirow[t]{2}{*}{ Various } & Unknown use & 3 & - \\
\hline & Diseases of internal organs & 1 & - \\
\hline \multirow[t]{2}{*}{ Form of application } & Macerate in Rakija ${ }^{a}$ & 40 & 20 \\
\hline & Water macerate & 13 & 10 \\
\hline
\end{tabular}

presented data of our study.

Rexhepi et al. (2013) evaluated traditional medicinal plant knowledge among Albanians, Macedonians, and Gorani in the Sharr Mountains (Montenegro). They mentioned the different uses of G. lutea in comparison to our study - to regulate temperature, and for respiratory system problems (influenza and cough).

Mustafa et al. (2015) studied a cross-cultural comparison of folk plant uses among Albanians, Bosniaks, Gorani, and Turks living in Kosovo. They mentioned the similar uses of G. lutea with our study against digestive disorders and as a flavor additive for an alcoholic beverage. Jarić et al. (2015) studied traditionally used plants on Suva Planina Mountains (Southeastern Serbia). They found that G. lutea can be used against abdominal pains, digestive, and strengthening the immune system, which was partially similar applications with the results of our investigations in the Pirot County.

In Eastern Albania, according to Pieroni et al. (2015), G. lutea was used as cardiotonic, which was a different use in comparison to our investigation in Pirot County. According to Śarić-Kundalić et al. (2010), yellow gentian was used against loss of appetite, and for strengthening of the organism, which were the identical uses, as well as against stomach ailments, for sedation, anemia, fever, and liver ailments, which was different use to that in the Pirot County.
Živković et al. (2020) were noted the uses of G. lutea against vein complaints and digestive problems, which were different, as well as against the loss of appetite, which was the same use as in the Pirot County.

In South Kosovo, according to (Mustafa et al., 2020), yellow gentian was traditionally used for blood, and ulcer of the stomach, which were the same uses in comparison with the results of our survey, and against heart diseases, and for better digestion which were the different uses as in our study.

\section{CONCLUSION}

This study provided a detailed review of the ethnopharmacological application of two medicinal plant species from the genus Gentiana which were noticed as medicinal plants among the population in the Pirot County, G. cruciata, and G. lutea. It includes great popularity and versatile aspects on traditional usage of G. cruciata and G. lutea, which make Pirot County interesting from the ethnobotanical point of view. Based on the results of interviews of the local population in Pirot County done in this study, it can be concluded that cross gentian (G. cruciata) is very popular and well known to people living in the rural area and that is frequently used for the treatment of various medical indications, especially for cancer diseases, improving the immune system, digestive disorders, and diabetes Yellow gentian (G. lutea) is also popular among the population of Pirot County, especially for improving the immune system, 
appetite, and stomach in the form of macerate in traditional fruit brandy.

Our results might be built-in in the commercial use of available plant species from the genus Gentiana in the study area Only exploitation in accordance with national legislative of protected species, conducted by experts, who have attended appropriate training, and possess collecting permits, can protect their natural habitats and sparse populations in nature. For the rural community, living in the mountain region of this economically poor region, promotion of traditional knowledge and practice, about plants from genus Gentiana, such as good natural conditions and possibility for their cultivation, close to their natural habitats, can provide an opportunity for economic development and higher standard of living in this area.

\section{FUNDING}

This research is part of the project: Ethnopharmacological study of the region of southeastern Serbia, O-02-17, supported by the Serbian Academy of Sciences and Arts.

\section{REFERENCES}

Dajić Stevanović, Z., Petrović, M. and Aćić, S. (2014). Ethnobotanical knowledge and traditional use of plants in Serbia in relation to sustainable rural development, in A. Pieroni and C. L. Quave (eds), Ethnobotany and Biocultural Diversities in the Balkans, Springer New York, New York, NY, pp. 229-252.

EMA (2018). European Union herbal monograph on Gentiana lutea I., radix, EMA/607861/2017 Committee on Herbal Medicinal Products (HMPC).

Euro+Med (2006-). Euro+Med PlantBase - the information resource for Euro-Mediterranean plant diversity., Published on the Internet. [accessed on 2021-09-22].

URL: https://ww2.bgbm.org/EuroPlusMed/query.asp

Janaćković, P., Gavrilović, M., Savić, J., Marin, P. and Dajić Stevanović, Z. (2019). Traditional knowledge of plant use from Negotin Krajina (Eastern Serbia): An ethnobotanical study, Indian Journal of Traditional Knowledge 18(1): 25-33.

Jarić, S., Mačukanović-Jocić, M., Djurdjević, L., Mitrović, M., Kostić, O. Karadžić, B. and Pavlović, P. (2015). An ethnobotanical survey of traditionally used plants on Suva planina mountain (south-eastern Serbia), Journal of Ethnopharmacology 175: 93-108.

Jarić, S., Mitrović, M., Karadžić, B., Kostić, O., Djurjević, L., Pavlović, M. and Pavlović, P. (2014). Plant resources used in Serbian medieval medicine. Ethnobotany and Ethnomedicine, Genetic Resources and Crop Evolution 61(7): 1359-1379.

Jordanov, D. (ed.) (1963-1979). Flora of Republic of Bulgaria., Vol. 1-7, Bulgarian Academy of Sciences, Sofia. [in Bulgarian].

Josifović, M. (ed.) (1970-1986). Flora of Republic of Serbia, Vol. 1-9, Serbian Academy of Sciences and Art, Belgrade. [in Serbian].

Marković, a., Stankov-Jovanović, V. and Smiljić, M. (2019). Medicinal flora of the Vidlič mountain in Serbia, The University Thought - Publication in Natural Sciences 9(1): 17-26.

Marković, M. (2019). Application of yarrow (Achillea millefolium L.) in ethnomedicine of the Pirot county (southeastern Serbia), Arhiv za farmaciju 69(5): 367-384.

Marković, M., Matović, M., Pavlović, D., Zlatković, B., Marković, A., Jotić, B. and Stankov-Jovanović, V. (2010). Resources of medicinal plants and herbs collector's calendar of Pirot County (Serbia), Biologica Nyssana 1(1-2): 9-21.

Marković, M., Pavlović-Muratspahić, D., Matović, M., Markovic, A. and Stankov-Jovanović, V. (2009). Aromatic flora of the Vidlič Mountain, Biotechnology \& Biotechnological Equipment 23(2): 1225-1229.

Marković, M., Rakonjac, L. and Nikolić, B. (2020). Medicinal plants of the Pirot County, Institute of Forestry, Belgrade. [in Serbian].

Menković, N., Šavikin, K., Tasić, S., Zdunić, G., Stešević, D., Milosavljević, S. and Vincek, D. (2011). Ethnobotanical study on traditional uses of wild medicinal plants in Prokletije Mountains (Montenegro), Journal of Ethnopharmacology 133(1): 97-107.

Mihajlov, M. and Milojević, B. (1985). Pharmacognosy map of the Pirot area, Proceedings of the Symposium "Centennial of Flora around Nis",
University of Nis, Faculty of Technology in Leskovac, Branch of the Serbian Biological Society, Nis., pp. 145-155.

Milojević, B. and Mihajlov, M. (1985). Folk terminology of medicinal herbs in the vicinity of Pirot, Proceedings of the Symposium "Centennial of Flora around Nis", University of Nis, Faculty of Technology in Leskovac, Branch of the Serbian Biological Society, Nis., pp. 167-180. [in Serbian].

Mustafa, B., Hajdari, A., Pieroni, A., Pulaj, B., Koro, X. and Quave, C. L. (2015). A cross-cultural comparison of folk plant uses among Albanians, Bosniaks, Gorani and Turks living in south Kosovo, Journal of Ethnobiology and Ethnomedicine 11(1): 39.

Mustafa, B., Hajdari, A., Pulaj, B., Quave, C. L. and Pieroni, A. (2020). Medical and food ethnobotany among Albanians and Serbs living in the Shtërpcë/Štrpce area, South Kosovo, Journal of Herbal Medicine 22: 100344

OGRS (2016). Ordinance on the proclamation and protection of strictly protected and protected wild species of plants, animals and fungi, Official Gazette of the Republic of Serbia no. 5/2010, 47/2011, 32/2016 and 98/2016

Pieroni, A., Dibra, B., Grishaj, G., Grishaj, I. and Gjon Maçai, S. (2005). Traditional phytotherapy of the Albanians of Lepushe, Northern Albanian Alps, Fitoterapia 76(3-4): 379-399.

Pieroni, A., Giusti, M. E. and Quave, C. L. (2011). Cross-cultural ethnobiology in the Western Balkans: Medical ethnobotany and ethnozoology among Albanians and Serbs in the Pešter Plateau, Sandžak, SouthWestern Serbia, Human Ecology 39(3): 333-349.

Pieroni, A., Ibraliu, A., Abbasi, A. M. and Papajani-Toska, V. (2015). An ethnobotanical study among Albanians and Aromanians living in the Rraicë and Mokra areas of Eastern Albania, Genetic Resources and Crop Evolution 62(4): 477-500.

Pieroni, A., Nedelcheva, A., Hajdari, A., Mustafa, B., Scaltriti, B., Cianfaglione, K. and Quave, C. L. (2014). Local knowledge on plants and domestic remedies in the mountain villages of Peshkopia (Eastern Albania), Journal of Mountain Science 11(1): 180-193.

Pieroni, A., Rexhepi, B., Nedelcheva, A., Hajdari, A., Mustafa, B. Kolosova, V., Cianfaglione, K. and Quave, C. L. (2013). One century later: the folk botanical knowledge of the last remaining Albanians of the upper Reka Valley, Mount Korab, Western Macedonia, Journal of Ethnobiology and Ethnomedicine 9(1): 22.

Randjelović, N., Stamenković, V. and Ilić, M. (1998). Manual on medicinal plants (picking, drying, storage, cultivation, processing and use of medicinal plants), Association of Student Cooperatives of Serbia DD "Zdravlje" Leskovac, Pirot - Leskovac.

Rexhepi, B., Mustafa, B., Hajdari, A., Rushidi-Rexhepi, J., Quave, C. L. and Pieroni, A. (2013). Traditional medicinal plant knowledge among Albanians, Macedonians and Gorani in the Sharr Mountains (Republic of Macedonia), Genetic Resources and Crop Evolution 60(7): 20552080.

Šarić-Kundalić, B., Dobeš, C., Klatte-Asselmeyer, V. and Saukel, J. (2010). Ethnobotanical study on medicinal use of wild and cultivated plants in middle, south and west Bosnia and Herzegovina, Journal of Ethnopharmacology 131(1): 33-55.

Sarić, M. (ed.) (1989). Medicinal plants of SR Serbia., Serbian Academy of Sciences and Arts, Belgrade.

Šavikin, K., Zdunić, G., Menković, N., Živković, J., Ćujić, N., Tereščenko, M. and Bigović, D. (2013). Ethnobotanical study on traditional use of medicinal plants in South-Western Serbia, Zlatibor district, Journal of Ethnopharmacology 146(3): 803-810.

Stankov-Jovanović, V., Šmelcerović, A., Smiljić, M., Ilić, M. and Marković, M. (2018). Ethnopharmacological application of St. John's wort in Pirot county, Pirotski zbornik 43: 141-164.

Tasić, S. (2012). Ethnobotany in see-wb countries; traditional uses of indigenous plants, Lekovite sirovine 32: 71-81. [in Serbian].

Tasić, S., Šavikin Fodulović, K. and Menković, N. (2001). Guide through the world of madicinal plants, Independent edition, Belgrade.

The Catalogue of Life Partnership. (2017). Iopi global plant checklist in the catalogue of life, Checklist dataset. [accessed via GBIF.org on202109-25].

URL: $h$ ttps://doi.org/10.15468/ottrss

Tutin, T., Heywood, V., Burges, N., Moore, D., Valentine, D., Walters, S. and Webb, D. (eds) (1964-1980). Flora Europaea, Vol. I-V, Cambrige University Press, London.

WHO (2007). Radix gentianae luteae, WHO monographs on selected medicinal plants, Vol. 3, World Health Organization, pp. 150-159. 
Živković, J., llić, M., Šavikin, K., Zdunić, G., llić, A. and Stojković, D. (2020). Traditional use of medicinal plants in South-Eastern Serbia (Pčinja district): Ethnopharmacological investigation on the current status and comparison with half a century old data, Frontiers in Pharmacology 11: 1020.

Zlatković, B. and Bogosavljević, S. (2014). Taxonomic and pharmacological valorization of the medicinal flora in Svrljiški Timok gorge (Eastern Serbia), Facta Universitatis Series: Medicine and Biology 16(2): 76-86.

Zlatković, B. K., Bogosavljević, S. S., Radivojević, A. R. and Pavlović, M. A. (2014). Traditional use of the native medicinal plant resource of Mt. Rtanj (Eastern Serbia): Ethnobotanical evaluation and comparison, Journal of Ethnopharmacology 151(1): 704-713. 